\title{
Solanine induced apoptosis and increased chemosensitivity to Adriamycin in T-cell acute lymphoblastic leukemia cells
}

\author{
YING-JIE YI ${ }^{1}$, XIU-HONG JIA ${ }^{1}$, JIAN-YONG WANG ${ }^{1}$, JIE-RU CHEN $^{1}$, HONG WANG $^{1}$ and YOU-JIE LI $^{2}$ \\ ${ }^{1}$ Department of Pediatrics, The Affiliated Hospital of Binzhou Medical University, Binzhou, Shandong 256603; \\ ${ }^{2}$ Department of Biochemistry and Molecular Biology, Key Laboratory of Tumour Molecular Biology, \\ Binzhou Medical University, Yantai, Shandong 264003, P.R. China
}

Received December 22, 2015; Accepted May 18, 2017

DOI: $10.3892 / \mathrm{ol} .2018 .8229$

\begin{abstract}
Solanine is an alkaloid and is the main extract of the traditional Chinese herb, Solanum nigrum Linn. It has been reported that Solanine has anti-inflammatory and antitumor properties. The present study aimed to investigate the antitumor effect of Solanine in Jurkat cells and demonstrate the molecular mechanism of antitumor activity of Solanine. A Cell Counting Kit- 8 assay demonstrated that Solanine inhibited the proliferation of Jurkat cells in a dose-and time-dependent manner. Cell apoptosis was measured by flow cytometry. Flow cytometry revealed that Solanine induced apoptosis in a dose-dependent manner in Jurkat cells. Reverse transcription-quantitative polymerase chain reaction demonstrated that Solanine modulated the mRNA levels of B-cell lymphoma-2 (Bcl-2) and Bcl-2-associated X protein (Bax). Additionally, Bcl-2 and Bax expression was measured using western blot analysis. Western blot analysis revealed a significant increase in the expression of Bax and decrease in the expression of Bcl-2. Solanine increased the chemosensitivity of Jurkat cells to Adriamycin. In summary, the present results indicated that the antitumor activity of Solanine was associated with inhibition of cell proliferation, induction of apoptosis and increasing cytotoxicity of Adriamycin. Therefore, Solanine may have potential as a novel agent for the treatment of acute lymphocytic leukemia.
\end{abstract}

\section{Introduction}

Acute lymphoblastic leukemia (ALL) is an aggressive type of blood cancer affecting children and adults, with peak prevalence between 2 and 5 years of age (1). T-cell ALL (T-ALL) is an aggressive hematological cancer that is caused by the malignant transformation of thymocyte progenitors (2).

Correspondence to: Professor Xiu-Hong Jia, Department of Pediatrics, The Affiliated Hospital of Binzhou Medical University, 661 Yellow River 2nd Road, Binzhou, Shandong 256603, P.R. China E-mail: jiaxiuhong001@163.com

Key words: Solanine, Jurkat cell, apoptosis, chemosensitivity
T-ALL accounts for $10-15 \%$ of pediatric and $25 \%$ of adult ALL cases $(2,3)$. The age of the patient at diagnosis, leukocyte count, ethnicity, gender and immunophenotype are clinical prognostic parameters that classify ALL patients into different risk groups (4). TALL is classified into a high-risk group in ALL (4). The prognosis of T-ALL has improved with the development of high-dose multi-agent chemotherapy, with a cure rate of $\sim 85 \%$ in children and $\sim 50 \%$ in adults (5). However, the treatment is often accompanied by severe acute toxicities and side effects, such as primary resistance, early relapse and secondary tumors $(2,3)$. The identification of new agents for T-ALL patients is urgently required.

Nightshade, a Chinese herbal medicine, has been used to treat sores, injuries, swelling and fractures (6). Solanine, the main extract of Nightshade, is a trisaccharide glycoalkaloid (7). Solanine has been demonstrated to inhibit the production of cytokine and nitric oxide in stimulated Jurkat cells LPS-stimulated Raw macrophages (8).

High concentrations of Solanine result in cytotoxicity-inducing damage of the plasma membrane, which causes disorder of metabolism, including reduced $\mathrm{NAD}(\mathrm{P}) \mathrm{H}$ productivity and the loss or inactivation of $\mathrm{NAD}(\mathrm{P}) \mathrm{H}$ :menadione reductase (9). Solanine was demonstrated to have a proliferation-inhibiting and apoptosis-promoting effect on multiple cancer cells, including prostate cancer, pancreatic carcinoma and melanoma cancer cells (6-9). Studies have also shown that Solanine suppresses proliferation and metastasis, and promotes apoptosis, in pancreatic cancer cells $(9,10)$. Solanine induces apoptosis of HepG2 cells by facilitating the opening of the PT channels in the mitochondria and suppressing the expression of Bcl-2 (11,12). Additionally, Solanine has been reported to inhibit human melanoma cells and human prostate cancer cell invasion at non-toxic doses $(6,7)$. However, to the best of our knowledge, the efficacy and the associated molecular mechanisms of Solanine promoting apoptosis in Jurkat cells have not been explored. In the present study, the effects of Solanine on the inhibition of proliferation and induction of apoptosis in Jurkat cells and the underlying molecular mechanism were investigated. Additionally, the effect of Solanine on the chemosensitivity of Jurkat cells to Adriamycin was assessed. The findings indicated the potential of Solanine to improve the therapeutic outcome of T-ALL. 


\section{Materials and methods}

Chemicals and reagents. Adriamycin (Melone Pharmaceutical Co. Ltd., Dalian, China) was dissolved to a concentration of $2 \mathrm{~g} / \mathrm{l}$ in $\mathrm{dH}_{2} \mathrm{O}$ and divided into 25 aliquots $(1.5 \mathrm{ml})$. Solanine (Sigma-Aldrich; Merck KGaA, Darmstadt, Germany) was dissolved in dimethyl sulfoxide (HyClone; GE Healthcare Life Sciences, Logan, UT, USA) to generate a stock solution $(100 \mu \mathrm{g} / \mathrm{ml})$, and diluted to each designated concentration in RPMI-1640 (HyClone; GE Healthcare Life Sciences). The rabbit polyclonal antibodies against B-cell lymphoma-2 (Bcl-2) and Bcl-2-associated X protein (Bax) were obtained from Beijing ZhongShan Golden Bridge Technology Co., Ltd. (Beijing, China). The rabbit polyclonal antibody against GADPH was obtained from Good here Biotechnology Co., Ltd., Hangzhou, China.

Cell lines and cell culture. The human T-ALL Jurkat cells were obtained from Key Laboratory of Tumour Molecular Biology of Binzhou Medical University (Binzhou, China). The cells were cultured in RPMI-1640 medium supplemented with $10 \%$ fetal bovine serum (HyClone; GE Healthcare Life Sciences) at $37^{\circ} \mathrm{C}$ in a humidified atmosphere containing $5 \% \mathrm{CO}_{2}$.

Cell proliferation assay. Cell Counting Kit 8 (CCK-8; Dojindo Molecular Technologies, Inc., Shanghai, China) was used to determine the cell viability in the presence of Solanine $(0,2,4,8$ or $16 \mu \mathrm{g} / \mathrm{ml})$, with/without $0.15 \mu \mathrm{g} / \mathrm{l}$ Adriamycin (4), incubated for $24 \mathrm{~h}$ at $37 \mathrm{at} 24 \mathrm{atedci}_{2}$ in air. Briefly, cells were seeded into 96 -well plates at a density of $1 \times 10^{4}$ cells/well, and, subsequent to treatment with Solamine $(0,24,6,8$ or $16 \mu \mathrm{g} / \mathrm{ml}$ ) with/without $0.15 \mu \mathrm{g} / \mathrm{l}$ Adriamycin, $10 \mu \mathrm{l} \mathrm{CCK}-8$ solution was added to each well and incubated for $4 \mathrm{~h}$ at $37^{\circ} \mathrm{C}$ in a humidified incubator with $5 \% \mathrm{CO}_{2}$ in air. Cells in control group were supplemented with the equivalent quantity of DMSO The absorbance was then measured at a wavelength of $490 \mathrm{~nm}$ using a fluorescence spectrofluorometer (F-7000; Hitachi Ltd., Tokyo, Japan). A blank well containing only medium and drugs was used as a control.

Flow cytometry analysis. The Jurkat cells $\left(3 \times 10^{5}\right.$ cells $\left./ \mathrm{ml}\right)$ were seeded into 6 well plates and incubated with various concentrations of Solanine $(0,4$ and $16 \mu \mathrm{g} / \mathrm{ml})$ for $24 \mathrm{~h}$ at $37^{\circ} \mathrm{C}$ in a humidified atmosphere containing $5 \% \mathrm{CO}_{2}$ in air. Cells were collected and washed twice with PBS. Cells were then suspended in binding buffer (KeyGen Biotech Co., Ltd., Nanjing, China) and double-stained with annexin V fluorescein isothiocyanate (FITC)/propidium iodide (PI; KeyGen Biotech Co., Ltd.) for $15 \mathrm{~min}$ in the dark at room temperature. The cell-associated mean fluorescence intensity (MFI) was detected by flow cytometer using a FACSCalibur (Beckman Coulter, Brea, CA, USA) to analyzed the apoptotic cells.

Determination of gene expression by reverse transcription-quantitative polymerase chain reaction $(R T-q P C R)$. Total RNA was isolated from Solanine-treated cells using TRIzol reagent (Invitrogen; Thermo Fisher Scientific, Inc., Waltham, MA, USA), according to the manufacturer's protocol. Reverse transcription was performed to generate first strand cDNA (Takara Biotechnology Co., Ltd., Dalian, China) using $2 \mu \mathrm{g}$ of total RNA. The reverse transcription reaction was implemented with PrimeScript ${ }^{\mathrm{TM}}$ RT reagent kit with gDNA Eraser (Takara Bio, Shiga, Japan). The primers (Table I) used in this experiment were designed using Primer 5 version 5.6.0 software (PREMIER Biosoft Co., Ltd., CA, USA) and synthesized by Sangon Biotech Co., Ltd., Shanghai, China.

qPCR was performed on an ABI PRISM 7500 qPCR system (Applied Biosystems; Thermo Fisher Scientific, Inc.) by using SYBRGreen reaction kit (Takara Bio, Inc., Otsu, Japan). The PCR reaction system consisted of SYBR Green reagent, forward and reverse primers, template cDNA and nuclease-free distilled water. The PCR conditions were $95^{\circ} \mathrm{C}$ for $30 \mathrm{sec}$, followed by 45 cycles of $95^{\circ} \mathrm{C}$ for $5 \mathrm{sec}$ and $60^{\circ} \mathrm{C}$ for $30 \mathrm{sec}$. GADPH was used as an internal control. qPCR for each gene of each cDNA sample was assayed in triplicate. The results were calculated using the $2^{-\Delta \Delta \mathrm{Cq}}$ method (4). The following equations were used: $\Delta \mathrm{Cq}=\mathrm{Cq}$ (target gene)-Cq (GADPH); $\Delta \Delta \mathrm{Cq}=\Delta \mathrm{Cq}$ (Solanine-treated cells)- $\Delta \mathrm{Cq}$ (untreated control).

Western blot analysis. The Jurkat cells were incubated with Solanine $(0,4$ or $16 \mu \mathrm{g} / \mathrm{ml})$ for $24 \mathrm{~h}$ at $37^{\circ} \mathrm{C}$. The cells were then harvested. Lysis buffer (100 $\mu$ l; Beyotime Institute of Biotechnology, Shanghai, China) was added and the protein concentration of the lysate was determined using a bicinchoninic acid protein assay kit (Beyotime Institute of Biotechnology). The lysed samples containing $50 \mu \mathrm{g}$ total protein were separated on 10-12\% SDS-PAGE (Beyotime Institute of Biotechnology), with a constant voltage of $80 \mathrm{~V}$ for $0.5 \mathrm{~h}$, and then $100 \mathrm{~V}$ for another $1.5 \mathrm{~h}$. The resolved proteins were electrophoretically transferred to polyvinylidene difluoride membranes (Merck $\mathrm{KGaA}$ ) and blocked with 5\% skimmed milk for $2 \mathrm{~h}$ at room temperature. Subsequently, the membranes were incubated overnight at $4^{\circ} \mathrm{C}$ with specific antibodies. The primary antibodies used were rabbit polyclonal antibodies against Bcl-2 (dilution, 1:500), Bax (dilution, 1:500) and GAPDH (dilution, 1:1,000). The following day, the membranes were incubated in horseradish peroxidase-labeled goat anti-rabbit immunoglobulin G (dilution, 1:5,000; catalog no., ZB-5301; Beijing ZhongShan Golden Bridge Technology Co., Ltd.) for $2 \mathrm{~h}$ at room temperature. Finally, images were captured using a FluorChem FC2 gel imaging system (ProteinSimple; Bio-Techne, Minneapolis, MN, USA). The intensity of each band was normalized by GADPH for their respective lanes.

Data analysis. Statistical analyses were performed using SPSS 13.0 software (SPSS, Inc., Chicago, IL, USA). Data are expressed as the mean \pm standard deviation. Differences between $\geq 3$ groups were evaluated by one-way analysis of variance followed by Student-Newman-Keuls test. Independent two sample t-tests were used to compare the differences between 2 groups. $\mathrm{P}<0.05$ was considered to indicate a statistically significant difference.

\section{Results}

Solanine decreased the viability of Jurkat cells. The ability of Solanine to inhibit Jurkat cell proliferation was assessed. Jurkat cells were treated with various concentrations of Solanine $(0,2,4,8$ or $16 \mu \mathrm{g} / \mathrm{ml})$ for 24,48 and $72 \mathrm{~h}$. Cell viability was 
determined by CCK- 8 assay. The results demonstrated that Jurkat cells were sensitive to Solanine, and Solanine inhibited Jurkat cell proliferation in a dose- and time-dependent manner (Fig. 1; $\mathrm{P}<0.05$ ).

Solanine induced Jurkat cell apoptosis. Subsequent to treatment of Jurkat cells with various concentrations of Solanine $(0,4$ and $16 \mu \mathrm{g} / \mathrm{ml}$ ) for $24 \mathrm{~h}$, the apoptotic rate of Jurkat cells was detected by flow cytometry to confirm that Solanine induces Jurkat cell apoptosis. The results revealed that Solanine promotes Jurkat cell apoptosis in a dose-dependent manner (Fig. 2; $\mathrm{P}<0.05$ ).

Effect of Solanine on mRNA levels of Bcl-2 and Bax. RT-qPCR analysis was performed to assess whether Solanine modulates the expression of Bcl-2 and Bax genes. The results showed that Bcl-2 mRNA level decreased and Bax mRNA level increased subsequent to treatment with various concentrations of Solanine (Fig. 3; $\mathrm{P}<0.05$ ).

Effect of Solanine on the expression of Bcl-2 and Bax protein in Jurkat cells. Bcl-2 and Bax are involved in cell apoptosis. The expression of $\mathrm{Bcl}-2$ and Bax was measured to explore the molecular mechanism underlying Solanine-induced apoptosis. The western blot assay showed that the expression of Bcl-2 decreased significantly while the expression of Bax increased subsequent to Jurkat cell incubation with various concentrations of Solanine for $24 \mathrm{~h}$ (Fig. 4 ; $\mathrm{P}<0.05)$.

Solanine enhanced chemosensitivity of Jurkat cells to Adriamycin. Based on the aforementioned findings, the present study explored whether Solanine could increase the chemosensitivity of Jurkat cells to Adriamycin. The cells were incubated with various concentrations of Solanine $(0,4$ and $16 \mu \mathrm{g} / \mathrm{ml})$ in the presence of Adriamycin for $24 \mathrm{~h}$, and inhibition of cell proliferation was measured by CCK-8 assay. As shown in Fig. 5, Solanine significantly increased the Adriamycin-induced inhibitory rate of Jurkat cell proliferation, which indicated that Solanine enhanced sensitivity to Adriamycin compared to the controls [Cells treated with Adriamycin $(0.15 \mu \mathrm{g} / \mathrm{l})$ in the absence of Solanine].

\section{Discussion}

Glycoalkaloids are secondary plant metabolites that contain nitrogen and are found in Solanaceous plants and possess anticarcinogenic activity (13). Solanine is a steroidal glycoalkaloid (9). Studies have shown that Solanine has antitumor potency (6-9), and inhibited the proliferation of U937 cells (14). In addition, data has shown that Solanine has antitumor activity in other types of cancer. Solanine has been shown to induce apoptosis of mice breast cancer cells by inducing Bax expression and decreasing Bcl-2 expression (14). Solanine also inhibited the activity of matrix metalloproteinase (MMP)-2 and MMP-9 by suppressing the phosphoinositide 3-kinase/Akt and c-Jun $\mathrm{N}$-terminal kinase signaling pathways at non-toxic doses, causing inhibition of migration and invasion in melanoma cells (7). Additionally, Solanine suppressed pancreatic cancer cell migration and invasion by inhibiting MMP-2 and MMP-9 expression (9,10). Solanine downregulated the Bcl-2/Bax ratio and processed the capase- 3 zymogen into an active form, thereby
Table I. Primers used in reverse transcription-quantitative polymerase chain reaction.

\begin{tabular}{clc}
\hline Gene & \multicolumn{1}{c}{ Primer sequence, 5'-3' } & $\begin{array}{c}\text { Product } \\
\text { length, bp }\end{array}$ \\
\hline $\begin{array}{c}\text { Bax } \\
\text { Forward } \\
\text { Reverse }\end{array}$ & CCGAGAGGTCTTTTTCCGAG & 117 \\
Bcl-2 & & \\
Forward & GGATTGTGGCCTTCTTTGAG & 152 \\
Reverse & TACCCAGCCTCCGTTATCCT & \\
GAPDH & & 121 \\
Forward & TGACTTCAACAGCGACACCCA & \\
Reverse & CACCCTGTTGCTGTAGCCAAA & \\
\hline
\end{tabular}

Bcl-2, B-cell lymphoma-2; Bax, Bcl-2-associated X protein.

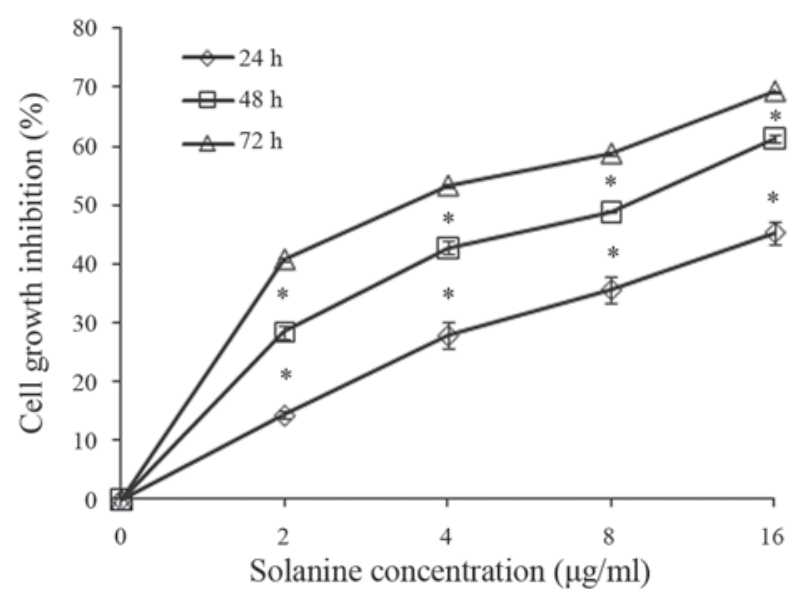

Figure 1. Solanine inhibited the proliferation of T-cell acute lymphoblastic leukemia Jurkat cells. Jurkat cells were treated with different concentrations of Solanine $(0,2,4,8$ and $16 \mu \mathrm{g} / \mathrm{ml})$ for 24,48 and $72 \mathrm{~h}$. Growth curves were based on data from Cell Counting Kit- 8 assays. Data are expressed as the mean \pm standard deviation of triplicate experiments. ${ }^{~} \mathrm{P}<0.05$ vs. $24 \mathrm{~h}$.

promoting pancreatic cancer cell apoptosis (10). However, to the best of our knowledge, the effect of Solanine on T-ALL cells remains unknown. The present study aimed to investigate the cellular functions of Solanine to elucidate the mechanism by which it contributes to promote apoptosis and inhibit proliferation in T-ALL Jurkat cells in vitro.

The CCK-8 assay showed that Solanine significantly inhibited Jurkat cell proliferation in a time- and dose-dependent manner (Fig. 1). Therefore, the results of the present study demonstrated that Solanine treatment inhibited T-ALL Jurkat cell proliferation in vitro.

Apoptosis, also termed programmed cell death, is characterized by morphological changes, including cell shrinkage, chromatin condensation and membrane blebbing without disruption of the plasma membrane (15). Apoptosis plays an important role in homeostasis (16). Therefore, apoptosis plays a crucial role in cancer treatment (17). In the present study, Solanine induced apoptosis of Jurkat cells, which was demonstrated by flow cytometry (Fig. 2). 

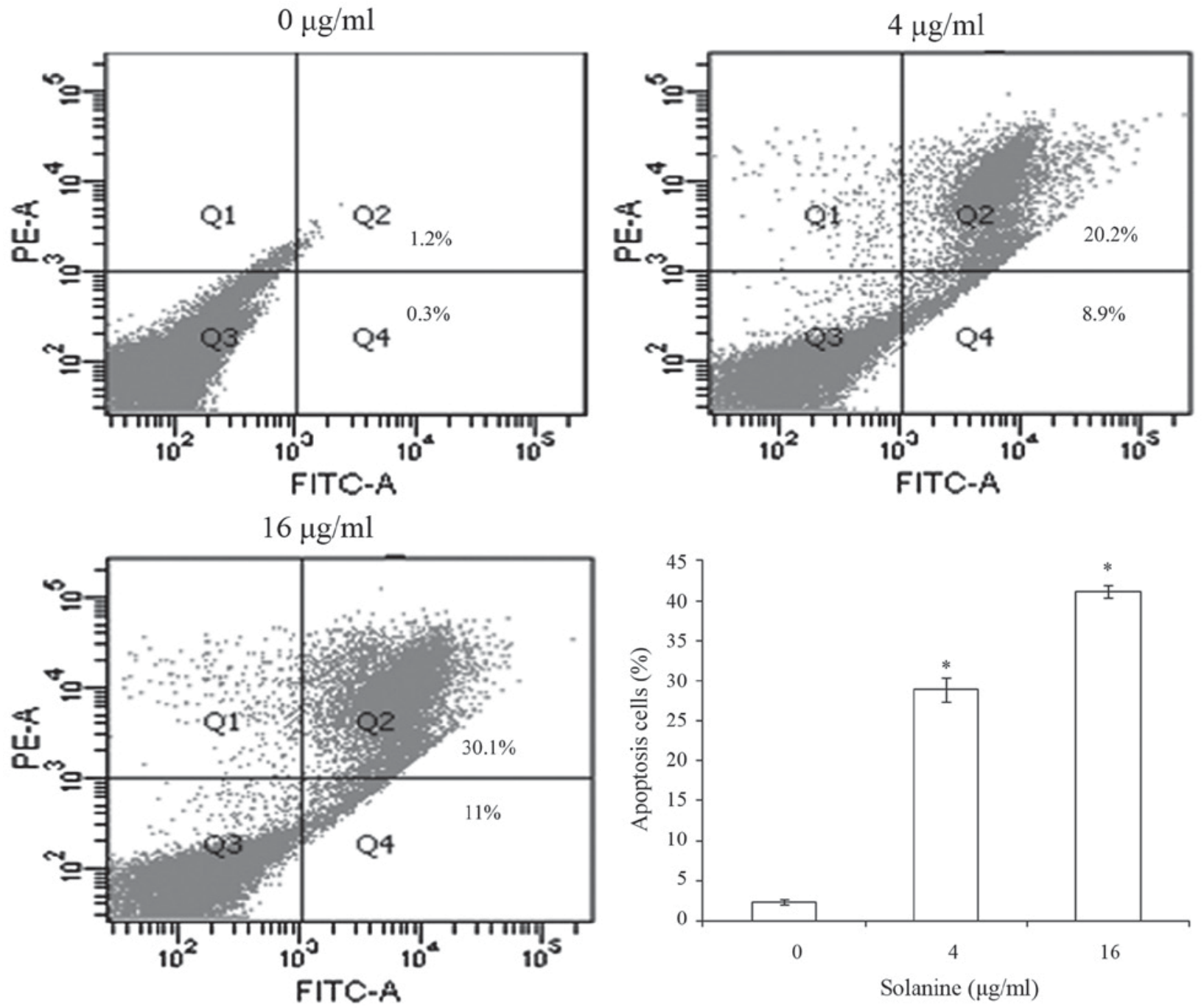

Figure 2. Solanine induced apoptosis in T-cell acute lymphoblastic leukemia Jurkat cells. Jurkat cells were treated with different concentrations of Solanine $(0,4$ and $16 \mu \mathrm{g} / \mathrm{ml})$ for $24 \mathrm{~h}$. Annexin VFITC/phycoerythirin staining was conducted in order to measure cell apoptosis. Data are expressed as the mean \pm standard deviation of triplicate experiments. "P<0.05 vs. $0 \mu \mathrm{g} / \mathrm{ml}$ Solanine. FITC, fluorescein isothiocyanate; PE, phycoerythrin.

Apoptosis is triggered by two pathways; one is the death receptor-mediated extrinsic pathway, and the other is the mitochondrial-dependent intrinsic pathway $(17,18)$. Bcl-2 family members are key components of the mitochondrial-dependent intrinsic apoptosis pathway (19). Bcl-2 family members are classified into three subgroups: The pro-apoptotic proteins, including Bax and Bak; the anti-apoptotic proteins, including $\mathrm{Bcl}-2$, myeloid cell leukemia-1 and Bcl-extra large; and the $\mathrm{BH} 3$-only proteins, including $\mathrm{BH} 3$ interacting domain death agonist, p53 upregulated modulator of apoptosis and Noxa (20). Bax and $\mathrm{Bcl}-2$ are the most characterized apoptosis regulators in mitochondrial-associated apoptosis (21). Bax was the first identified pro-apoptotic protein member of the Bcl-2 protein family, which is able to promote apoptosis (21). In the presence of apoptotic stimuli, Bax translocates to the mitochondria, promoting the release of cytochrome $\mathrm{c}$ into the cytosol, leading ultimately to apoptotic cell death (22). Bcl-2, a major anti-apoptotic protein of the Bcl-2 family inhibits cells apoptosis by protecting mitochondrial membrane integrity and blocking the release of cytochrome c (22). The Bax/Bcl-2 ratio determines whether a cell will survive or undergo apoptosis (18). It has been reported that a reduced level of Bax and increased level of Bcl-2 affect the relapse rate of patients with ALL (21). In the present study, RT-qPCR revealed that Solanine inhibited Bcl-2 and promoted Bax mRNA expression (Fig. 3). In addition, the results of the present study indicated that Solanine increased Bax protein expression and decreased Bcl-2 protein expression in a dose-dependent manner, promoting the apoptosis of Jurkat cells (Fig. 4). Therefore, the results of the present study confirmed that Solanine regulates the expression of apoptosis-associated genes and proteins in the T-ALL Jurkat cell line.

Adriamycin is a highly effective anthracycline that is widely used in chemotherapy treatment of a wide range of cancer, including leukemia. In the present study, it was demonstrated that Solanine significantly enhanced the cytotoxicity of Adriamycin in T-ALL cells. The results indicated that Solanine may sensitize T-ALL cells to Adriamycin. The results from the present study indicated the potential of Solanine as an attractive therapeutic strategy for T-ALL.

In conclusion, the present results indicated that Solanine possesses antitumor activity in Jurkat cells. Additionally, 

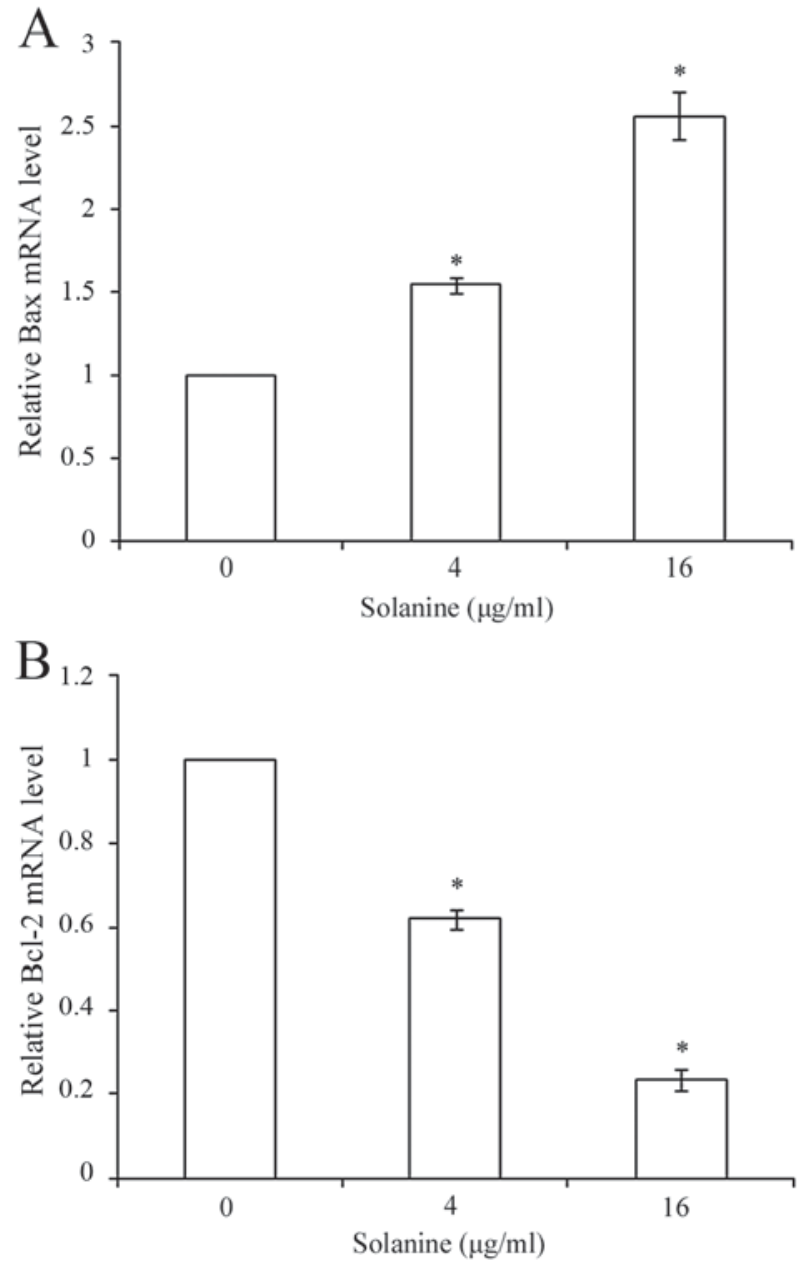

Figure 3. Effect of Solanine on (A) Bax and (B) Bcl-2 mRNA expression in Jurkat cells. The Jurkat cells were treated with different concentrations of Solanine $(0,4$ and $16 \mu \mathrm{g} / \mathrm{ml})$ for $24 \mathrm{~h}$ before Bcl-2 and Bax mRNA levels were determined by reverse transcription-quantitative polymerase chain reaction. Data are expressed as the mean \pm standard deviation of triplicate experiments. ${ }^{*} \mathrm{P}<0.05$ vs. vs. $0 \mu \mathrm{g} / \mathrm{ml}$ Solanine. Bcl-2, B-cell lymphoma-2; Bax, Bcl-2-associated X protein.

the results showed that the anticancer activity of Solanine in Jurkat cells may be associated with inhibition of proliferation and induction of apoptosis by regulating the expression of apoptosis-associated genes and proteins. Solanine may significantly increase the chemosensitivity of Jurkat cells to Adriamycin. Therefore, these findings may provide a novel approach for the development of T-ALL therapy using Solanine.

\section{Acknowledgements}

This study was supported by the Natural Science Foundation of Shandong Province (grant no. ZR2014HL032), Projects of Medical and Health Technology Development Program in Shandong Province (grant no. 2014WS0183) and Shandong Science and Technology Committee (grant no. 2010GSF10264).

\section{Competing interests}

The authors declare that they have no competing interests.
A

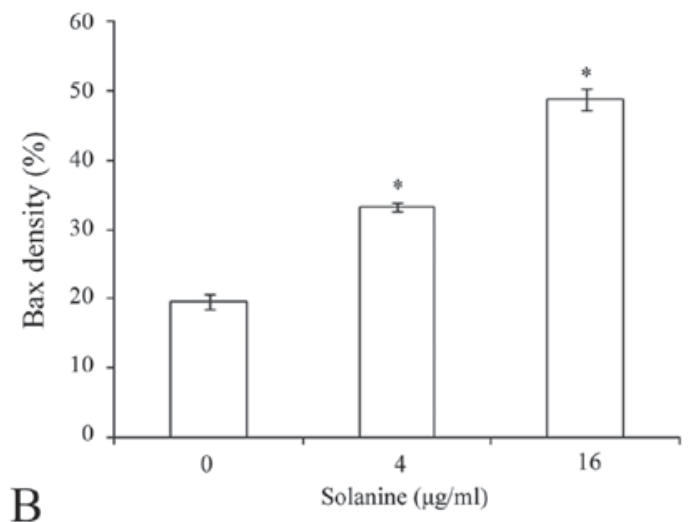

B

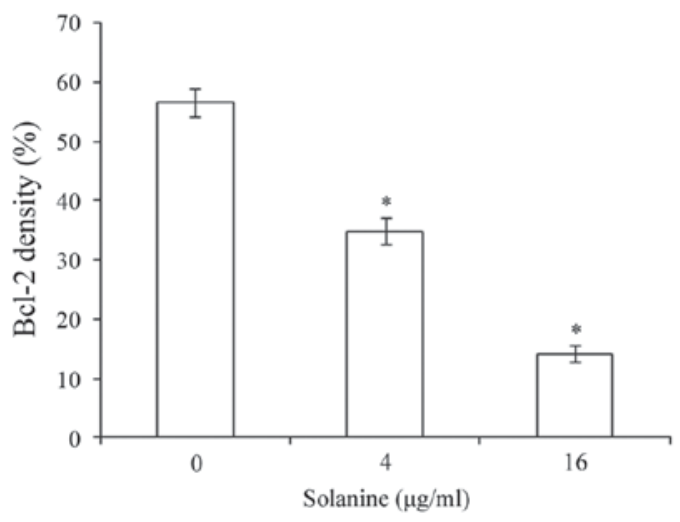

C Solanine $(\mu \mathrm{g} / \mathrm{ml})$ $\begin{array}{lll}0 & 4 & 16\end{array}$

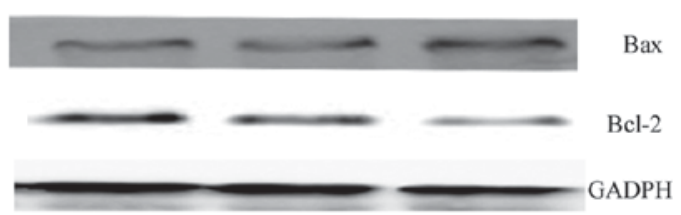

Figure 4. Effect of Solanine treatment on (A) Bax and (B) Bcl-2 expression in T-cell acute lymphoblastic leukemia Jurkat cells. Jurkat cells were treated with Solanine $(0,4$ and $16 \mu \mathrm{g} / \mathrm{ml})$ for $24 \mathrm{~h}$. (C) Protein expression levels of Bcl-2 and Bax were measured by western blot analysis. GAPDH was used as a positive control. Data are expressed as the mean \pm standard deviation of triplicate experiments. ${ }^{*} \mathrm{P}<0.05$ vs. $0 \mu \mathrm{g} / \mathrm{ml}$ Solanine. Bcl-2, B-cell lymphoma-2; Bax, Bcl-2-associated X protein.

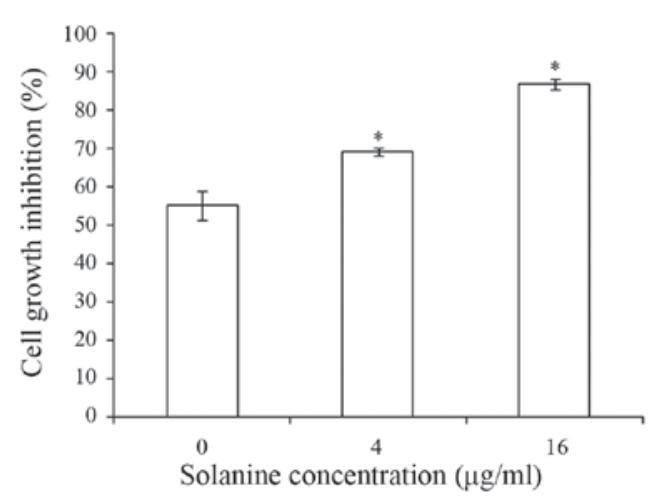

Figure 5. Effect of Solanine on the chemosensitivity of Jurkat cells to Adriamycin. Cell viability was measured by Cell Counting Kit- 8 assay subsequent to treatment with Solanine in the presence of Adriamycin $(2 \mu \mathrm{g} / \mathrm{ml}$ for $24 \mathrm{~h})$. Data are expressed as the mean \pm standard deviation of triplicate experiments. ${ }^{*} \mathrm{P}<0.05$ vs. $0 \mu \mathrm{g} / \mathrm{ml}$ Solanine in the presence of 2 $\mu \mathrm{g} / \mathrm{ml}$ Adriamycin. 


\section{References}

1. Chopra A, Soni S, Verma D, Kumar D, Dwivedi R, Vishwanathan A, Vishwakama G, Bakhshi S, Seth R, Gogia A, et al: Prevalence of common fusion transcripts in acute lymphoblastic leukemia: A report of 304 cases. Asia Pac J Clin Oncol 11: 293-298, 2015.

2. Durinck K, Goossens S, Peirs S, Wallaert A, Van Loocke W, Matthijssens F, Pieters T, Milani G, Lammens T, Rondou P, et al: Novel biological insights in T-cell acute lymphoblastic leukemia. Exp Hematol 43: 625-639, 2015.

3. D'Angelo V, Iannotta A, Ramaglia M, Lombardi A, Zarone MR, Desiderio V, Affinita MC, Pecoraro G, Di Martino M, Indolfi P, et al: $\mathrm{EZH} 2$ is increased in paediatric T-cell acute lymphoblastic leukemia and is a suitable molecular target in combination treatment approaches. J Exp Clin Cancer Res 34: 83, 2015.

4. Livak KJ and Schmittgen TD: Analysis of relative gene expression data using real-time quantitative PCR and the 2(-Delta Delta C(T)) method. Methods 25: 402-408, 2001.

5. Akahane K, Sanda T, Mansour MR, Radimerski T, DeAngelo DJ, Weinstock DM and Look AT: HSP90 inhibition leads to degradation of the TYK2 kinase and apoptotic cell death in T-cell acute lymphoblastic leukemia. Leukemia 30: 219-228, 2016.

6. Shen KH, Liao AC, Hung JH, Lee WJ, Hu KC, Lin PT, Liao RF and Chen PS: $\alpha$-solanine inhibits invasion of human prostate cancer cell by suppressing epithelial-mesenchymal transition and MMPs expression. Molecules 19: 11896-11914, 2014.

7. Lu MK, Shih YW, Chang Chien TT, Fang LH, Huang HC and Chen PS: $\alpha$-solanine inhibits human melanoma cell migration and invasion by reducing matrix metalloproteinase-2/9 activities. Biol Pharm Bull 33: 1685-1691, 2010.

8. Kenny OM, McCarthy CM, Brunton NP, Hossain MB, Rai DK, Collins SG, Jones PW, Maguire AR and O'Brien NM: Anti-inflammatory properties of potato glycoalkaloids in stimulated Jurkat and Raw 264.7 mouse macrophages. Life Sci 92 775-782, 2013

9. Lv C, Kong H, Dong G, Liu L, Tong K, Sun H, Chen B, Zhang C and Zhou M: Antitumor efficacy of $\alpha$-solanine against pancreatic cancer in vitro and in vivo. PLoS One 9: e87868, 2014.

10. Sun H, Lv C, Yang L, Wang Y, Zhang Q, Yu S, Kong H, Wang M, Xie J, Zhang C and Zhou M: Solanine induces mitochondria-mediated apoptosis in human pancreatic cancer cells. Biomed Res Int 2014: 805926, 2014.

11. Gao SY, Wang QJ and Ji YB: Effect of solanine on the membrane potential of mitochondria in HepG2 cells and [Ca2+]i in the cells. World J Gastroenterol 12: 3359-3367, 2006.
12. Ji YB, Gao SY, Ji CF and Zou X: Induction of apoptosis in HepG2 cells by solanine and Bcl-2 protein. J Ethnopharmacol 115: 194-202, 2008

13. Friedman M: Chemistry and anticarcinogenic mechanisms of glycoalkaloids produced by eggplants, potatoes, and tomatoes. J Agric Food Chem 63: 3323-3337, 2015.

14. Friedman M, Lee KR, Kim HJ, Lee IS and Kozukue N: Anticarcinogenic effects of glycoalkaloids from potatoes against human cervical, liver, lymphoma, and stomach cancer cells. J Agric Food Chem 53: 6162-6169, 2005.

15. Kwak CH, Lee SH, Lee SK, Ha SH, Suh SJ, Kwon KM, Chung TW, Ha KT, Chang YC, Lee YC, et al: Induction of apoptosis and antitumor activity of eel skin mucus, containing lactose-binding molecules, on human leukemic K562 cells. Mar Drugs 13: 3936-3949, 2015.

16. Scarfò L and Ghia P: Reprogramming cell death: BCL2 family inhibition in hematological malignancies. Immunol Lett 155: 36-39, 2013

17. Qi L, Ren K, Fang F, Zhao DH, Yang NJ and Li Y: Over expression of BCL2 and low expression of caspase 8 related to TRAIL resistance in brain cancer stem cells. Asian Pac J Cancer Prev 16: 4849-4852, 2015

18. Christodoulou MI, Kontos CK, Halabalaki M, Skaltsounis AL and Scorilas A: Nature promises new anticancer agents: Interplay with the apoptosis-related BCL2 Gene Family. Anticancer Agents Med Chim 14: 375-399, 2014.

19. Wang S, Zhou M, Ouyang J, Geng $Z$ and Wang Z: Tetraarsenictetrasulfide and arsenic trioxide exert synergistic effects on induction of apoptosis and differentiation in acute promyelocytic leukemia Cells. PLoS One 10: e0130343, 2015.

20. Subburaj Y, Cosentino K, Axmann M, Pedrueza-Villalmanzo E, Hermann E, Bleicken S, Spatz J and García-Sáez AJ: Bax monomers form dimer units in the membrane that further self-assemble into multiple oligomeric species Introduction. Nat Commun 6: 8042,2015

21. Cingeetham A, Vuree S, Dunna NR, Gorre M, Nanchari SR, Edathara PM, Meka P, Annamaneni S, Digumarthi R, Sinha S and Satti V: Influence of BCL2-938C $>$ A and BAX-248G $>$ A promoter polymorphisms in the development of AML: Case-control study from South India. Tumour Biol 36: 7967-7976, 2015.

22. Stamati L, Avgeris M, Kosmidis H, Baka M, Anastasiou T, Piatopoulou D, Scorilas A and Gourgiotis D: Overexpression of BCL2 and BAX following BFM induction therapy predicts ch-ALL patients' poor response to treatment and short-term relapse. J Cancer Res Clin Oncol 141: 2023-2036, 2015. 